\title{
Peptide immunotherapy for childhood allergy - addressing translational challenges
}

Karen J Mackenzie ${ }^{1,2}$, Stephen M Anderton ${ }^{1,3}$ and Jürgen Schwarze ${ }^{1,2^{*}}$

\begin{abstract}
Allergic sensitisation usually begins early in life. The number of allergens a patient is sensitised to can increase over time and the development of additional allergic conditions is increasingly recognised. Targeting allergic disease in childhood is thus likely to be the most efficacious means of reducing the overall burden of allergic disease. Specific immunotherapy involves administering protein allergen to tolerise allergen reactive CD4 ${ }^{+} \mathrm{T}$ cells, thought key in driving allergic responses. Yet specific immunotherapy risks allergic reactions including anaphylaxis as a consequence of preformed allergen-specific IgE antibodies binding to the protein, subsequent cross-linking and mast cell degranulation. $\mathrm{CD}^{+} \mathrm{T}$ cells direct their responses to short "immunodominant" peptides within the allergen. Such peptides can be given therapeutically to induce T cell tolerance without facilitating IgE cross-linking. Peptide immunotherapy (PIT) offers attractive treatment potential for allergic disease. However, PIT has not yet been shown to be effective in children. This review discusses the immunological mechanisms implicated in PIT and briefly covers outcomes from adult PIT trials. This provides a context for discussion of the challenges for the application of PIT, both generally and more specifically in relation to children.
\end{abstract}

Keywords: Allergy, Children, Peptide Immunotherapy

\section{Introduction}

Allergic disease including atopic eczema, allergic rhinitis, allergic asthma and food allergy causes significant patient morbidity and economic costs to healthcare systems [1,2]. Current clinical management primarily relies on allergen avoidance, treating symptoms as they arise (often using medications such as $\beta 2$ agonist inhalers, antihistamines and adrenaline) and generalised suppression of immune responses (e.g. using corticosteroids). Therapeutic blockade of cytokines such as interleukin-5 (IL-5) and of IgE have had varied clinical results and such approaches are reserved for highly selected patient groups at present [3-5]. Many allergic patients will first experience symptoms during childhood [6] and allergic sensitisation may begin very early in infancy, even prenatally $[7,8]$. Children with atopy are at risk of developing new sensitisations and additional allergic conditions as they get older [1,9]. Identifying atopic children early

\footnotetext{
* Correspondence: Jurgen.Schwarze@ed.ac.uk

'MRC Centre for Inflammation Research, The University of Edinburgh,

Edinburgh, UK

Full list of author information is available at the end of the article
}

and modifying disease progression is therefore a hugely attractive therapeutic goal [10].

Evidence suggests a key role for $\mathrm{CD} 4^{+} \mathrm{T}$ cells, particularly the $\mathrm{T}$ helper (Th) 2 subset, in allergy. These cells express the transcription factor GATA-binding protein 3 (GATA-3) and can produce allergy-associated cytokines such as IL-4, IL-5 and IL-13 which are implicated in a host of allergic responses such as eosinophil recruitment and airway hyperreactivity [reviewed in [11]]. Th2 cells also provide B cells with help, driving immunoglobulin class-switching towards allergen-specific IgE [11]. Less commonly, and often in concert with Th2 cells, other helper subsets such as Th1, Th17 and Th9 cells have also been implicated in the pathogenesis of allergic asthma in some patients [reviewed in [12]]. Therapeutic targeting of allergen-reactive $\mathrm{CD} 4^{+} \mathrm{T}$ cells therefore has the capacity to abrogate downstream allergic responses [11]. One way of doing this is through specific immunotherapy (SIT) which targets $\mathrm{CD}_{4}^{+} \mathrm{T}$ cells via the administration of protein allergen. First used over a century ago [13], much of SIT's therapeutic effects have been shown to result from the induction of tolerance of allergen-reactive $\mathrm{CD} 4^{+} \mathrm{T}$ cells so they no longer mount
C Biomed Central 
an allergic response to the allergen. This can occur either through direct effects on allergen-reactive $\mathrm{T}$ cells and/or through the actions of $\mathrm{T}$ regulatory cells [14]. SIT can significantly improve symptoms in allergic patients [15], therapeutic effects can be long-lasting [16] and SIT for allergic rhinitis may reduce the likelihood of future asthma development [reviewed in [17]]. Yet SIT can also be risky. Pre-existing allergen-specific IgE can bind to multiple sites on protein allergen, leading to IgE cross-linking on mast cells, inducing mast cell degranulation and subsequent allergic reactions, even anaphylaxis [18-20].

Such SIT-associated risks can be overcome by identifying short peptides from within the protein allergen to which the $\mathrm{CD}^{+}{ }^{+} \mathrm{T}$ cell response is directed [10]. Such "immunodominant" peptides can bind efficiently to major histocompatibility complex II (MHC II) to induce $\mathrm{T}$ cell responses and can therefore be used to generate $\mathrm{T}$ cell tolerance, while their short length and lack of tertiary conformational structure do not facilitate IgE cross-linking [21]. Such therapeutic application of peptides [hereafter referred to as peptide immunotherapy (PIT)] was first developed in rodent autoimmune disease models [22]. However, clinical translation of PIT has been faster for allergy than for autoimmune disease [10]. The early manifestation and often progressive nature of allergic disease means that maximising PIT's disease-modifying potential would require targeting allergic children (Figure 1). However, clinical trials of PIT have so far not included children and the need for scrupulous safety concerning novel paediatric treatments necessitates further understanding of the mechanisms involved in successful PIT.

\section{Immunological mechanisms of PIT}

PIT harnesses the body's capacity to induce peripheral $\mathrm{T}$ cell tolerance. This capacity is paramount to prevent inflammatory responses both to harmless exogenous antigens and to self antigens [23]. Lack of pathogenassociated or inflammation-associated "danger signals" in such circumstances promote a tolerogenic rather than an inflammatory response. Hence, administering a soluble peptide in the absence of danger signals (e.g. in the absence of lipolysaccharide (LPS) and/or an adjuvant) can induce tolerance, whereas administration of the same peptide with an adjuvant promotes an inflammatory/immunogenic response [21]. Soluble peptides administered by intranasal, oral, intravenous, subcutaneous and intradermal routes all have the potential to induce tolerance [24-27].

\section{Dendritic cells}

In order to elicit a $\mathrm{T}$ cell response, peptide must be presented to $\mathrm{T}$ cells by antigen presenting cells in the context of MHC II, facilitating engagement of the $\mathrm{T}$ cell receptor (TCR). Dendritic cells (DCs), antigen presenting cells optimally able to stimulate $\mathrm{T}$ cells, are strongly implicated in driving tolerance. CD11c-deficient mice (lacking conventional DCs, plasmacytoid DCs and Langerhans cells) develop spontaneous autoimmunity, implicating DCs in the maintenance of peripheral

\section{Infant Child Adolescent \\ Foetus}

Age

Allergic Sensitisation

Number of Allergic Conditions

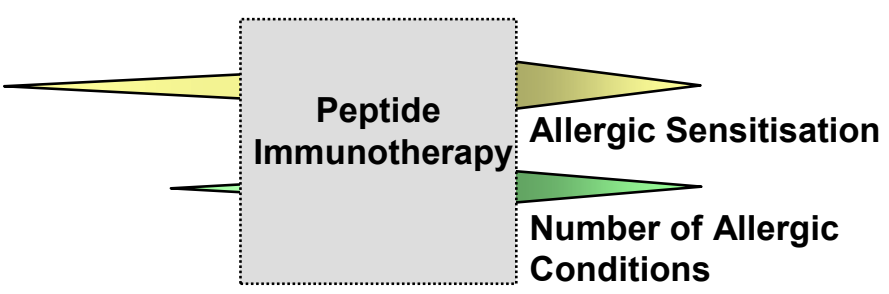

Figure 1 Proposed model of the effects of PIT on disease progression in children with severe atopy. Evidence suggests that in susceptible individuals, allergic sensitisation begins early in life, even prenatally, preceding development of allergic conditions such as eczema. The number of allergens an individual is sensitised to and the number of diagnosed allergic conditions can increase with age. Inducing tolerance to an allergen using PIT early, rather than later, in life has the potential to reduce sensitisation to additional allergens and reduce the risk of progression to multiple allergic conditions particularly for children with severe atopy. 
tolerance [28]. Peptide is rapidly presented on DCs after therapeutic administration [29]. It appears that the activation status of the $\mathrm{DC}$ is the prime orchestrator of whether or not a $\mathrm{T}$ cell becomes tolerant since "immature" DCs expressing low levels of costimulatory molecules have been found to induce $\mathrm{T}$ cell tolerance, in contrast to activated DCs $[25,30]$. Considering that different DC subtypes may be tissue-specific with particular anti-inflammatory or pro-inflammatory characteristics [31], the nature of DC-T cell interactions, and hence the mechanism of tolerance induction, could vary with different PIT delivery routes.

\section{$T$ cells and the 3 Pillars of Tolerance}

The strength of the TCR signal induced by a peptide can affect the outcome of PIT. Peptides with strong MHC II avidity form a stable peptide-MHC II interaction, hence generate a strong TCR signal and have an improved ability to induce tolerance [32]. This may be due to a resultant rapid, and synchronous $\mathrm{T}$ cell response [33]. Studies, predominantly in mice, have shown that the induction of $\mathrm{T}$ cell tolerance is likely to be effected by three fundamental mechanisms - deletion, adaptation and regulation [34]. All have variably been thought to contribute to the effects of PIT [25-27,35,36], however, certain mechanisms may be more therapeutically desirable than others.

\section{Deletion}

PIT can lead to targeted deletion of $\mathrm{CD}^{+} \mathrm{T}$ cells [25]. This mechanism is advantageous in that deletion removes the possibility of such cells reverting to pathogenicity in the future. High dose PIT and/or induction of a strong but transient TCR signal appear to favour deletion [25,37].

\section{Adaptation}

$\mathrm{T}$ cells can also be rendered tolerant through anergy - a state of unresponsiveness. A particular form of $\mathrm{T}$ cell anergy, known as adaptive tolerance, may be most relevant in vivo [38]. Adaptive tolerance is associated with inhibition of proliferation and cytokine production and has been demonstrated, to varying degrees, to occur after PIT in several murine and human studies $[35,36,39-41]$. One drawback is that adaptive tolerance is not necessarily permanent, and persistence of the peptide may be required to maintain tolerance [39]. Hence, adaptive tolerance alone may be insufficient to maintain long-term therapeutic effects after a short course of treatment.

\section{Regulation}

Several subsets of $\mathrm{T}$ regulatory cells capable of constraining immune responses have been described [reviewed in [42]]. Generating regulatory $\mathrm{T}$ cells using PIT is therapeutically desirable because of the potential for long-lived suppression of unwanted allergic responses. Using PIT to induce allergen-reactive $\mathrm{T}$ regulatory cells also has the potential to down-regulate responses to other allergens. This "bystander suppression" [10] could be particularly beneficial in the allergic lung where multiple potential allergens are continually encountered, and because allergic lung inflammation has been found to increase the likelihood of developing allergic sensitisation to additional aeroallergens [43].

Different $\mathrm{T}$ regulatory cell subsets vary in their mechanism(s) of action and whether or not they express the transcription factor Foxp3. In fact, there are limited data concerning the ability of PIT to induce Foxp $3^{+} \mathrm{T}$ regulatory cells. That said, peptide-reactive Foxp $3^{+} \mathrm{T}$ regulatory cells were generated in a model using a peptide complex designed to specifically target peptide to DCs, ensuring peptide uptake and presentation [44]. Interestingly, generation of Foxp $3^{+} \mathrm{T}$ regulatory cells was reduced using high dose peptide or when peptide was presented by activated DCs [44].

One means whereby $\mathrm{T}$ regulatory cells often effect regulation is via production of immunosuppressive cytokines such as IL-10. In beekeepers, the frequency of IL10 producing allergen-reactive $\mathrm{T}$ cells has been found to increase following tolerance induction to bee venom, which develops naturally in response to multiple bee stings [45]. Some murine studies of PIT have clearly demonstrated peptide-reactive $\mathrm{T}$ regulatory cells as the source of IL-10 following PIT [26]. IL-10 was also implicated in the therapeutic effects of PIT in a mouse model of allergic airways disease [35]. In one clinical study, IL10 production increased from allergen-reactive $\mathrm{T}$ cells after PIT [36] and, in another, $\mathrm{CD} 4^{+} \mathrm{T}$ cells obtained from patients after PIT had suppressive activity in vitro [40]. It appears that the development of regulatory mechanisms following PIT may be favoured by regimens using repeated peptide dosing [26], however the optimal dosage and delivery regimes favouring regulation remain unclear.

Overall, therapeutic targeting of allergen-reactive (principally $\mathrm{Th} 2$ ) $\mathrm{CD}^{+}{ }^{+} \mathrm{T}$ cells using PIT could, therefore, occur via deletion, adaptation, or regulation, or most probably a combination of these, echoing the varied mechanisms attributed previously to clinical effectiveness following SIT [[46,47] and reviewed in [14]]. By targeting allergen-specific $\mathrm{CD}_{4}^{+} \mathrm{T}$ cells, and consequently modulating the provision of B cell help, PIT has also been found to be capable of beneficially altering allergen-specific antibody levels in some studies [[35] and discussed in [48]]. While deletion or adaptation of allergen-reactive Th2 cells should reduce allergic responses to that particular allergen (in part because reductions in Th2 cytokine production should inhibit the recruitment of innate immune cells such as eosinophils), the induction of regulatory mechanisms also confers the potential to suppress allergic responses to a 
variety of other allergens and is thus particularly advantageous. Existing data from limited human studies of PIT and from experimental murine PIT models (discussed above) indicate that the mechanism of tolerance induction that predominates following PIT is likely to be influenced by factors such as the nature of disease, the dose of peptide and the delivery route (Figure 2).

\section{PIT in adult allergy trials}

Since the first clinical PIT trial in adult allergic patients in the 1990s [49] significant advances have been made, but as yet there are no PIT studies involving children. The majority of clinical PIT studies have utilised peptides from the major cat allergen Fel d 1. The outcomes from these trials have been comprehensively reviewed previously [24] and will therefore not be covered in detail here. Briefly, however, initial trials used two 27 amino acid immunodominant Fel d 1 peptides. In those studies, short term improvements in lung function tests and improvements in clinical symptoms were described to a variable extent [49-52]. More recently, there has been a move towards using shorter peptides, typically 15-17 amino acids in length. For Fel d 1, these were administered in the form of multiple, overlapping peptides encompassing the majority of the Fel $\mathrm{d} 1$ protein. This has the advantage of maximising the number of allergen-reactive $\mathrm{T}$ cells that may be tolerised since patients may respond to multiple immunodominant peptides and immunodominant peptides may vary between individuals with different HLA types. Using

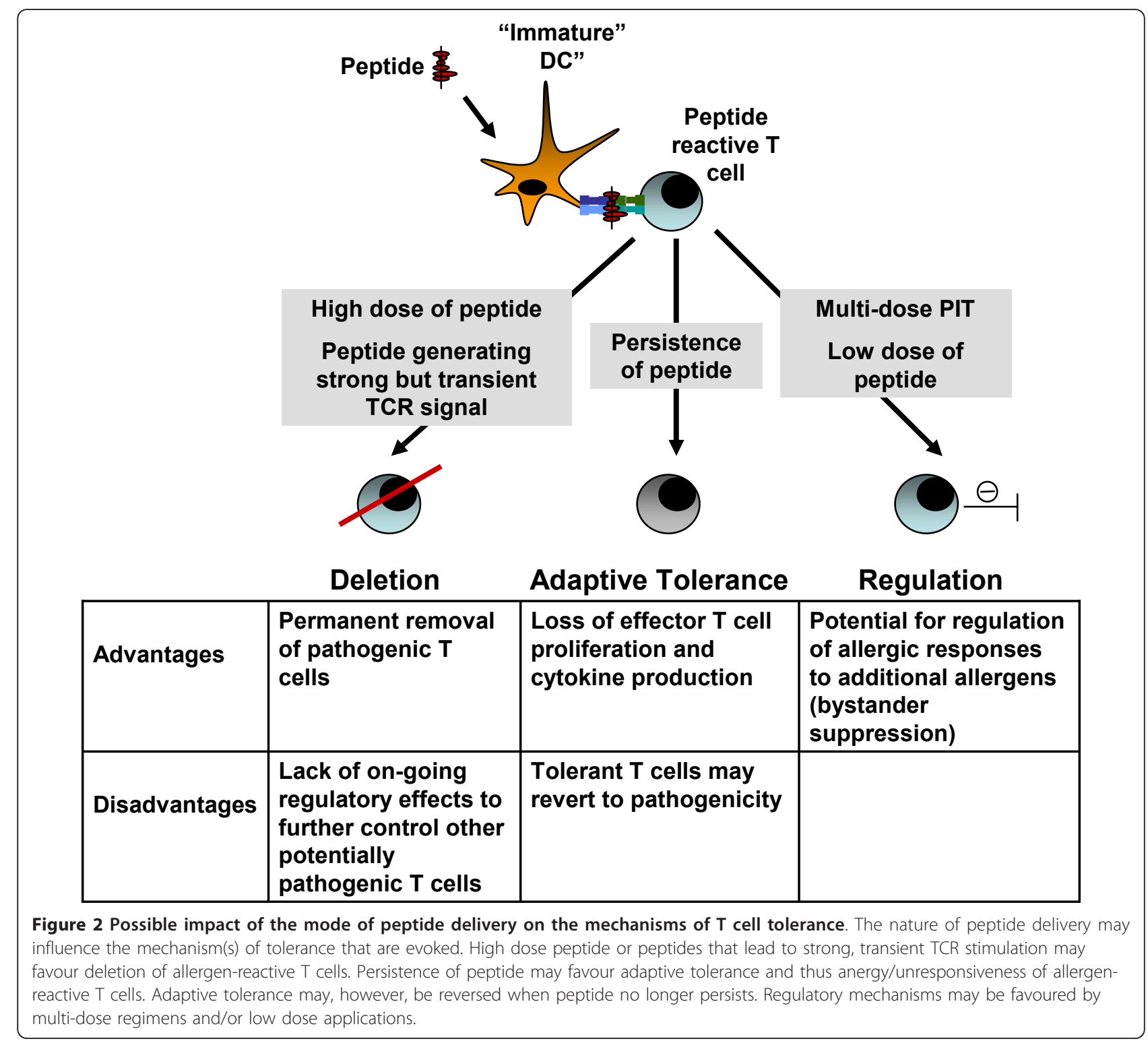


shorter peptides also abrogated the risk of allergen-specific IgE binding which had occasionally been reported in studies using longer peptides [50]. This approach using multiple short, overlapping peptides reduced latephase skin reactions to cat allergen, reduced proliferation of peripheral blood mononuclear cells (PBMC) to cat allergen and improved symptoms in some patients $[53,54]$. In one study, PBMC responses to Fel d 1 peptides not included in the treatment vaccine were also reduced, implying linked-suppression, whereby tolerance induced to one peptide inhibits responses to other peptides within the same protein [35].

PIT also offers a potentially safer approach to allergen-specific immunotherapy for bee venom allergy, where SIT has a high frequency of severe allergic reactions [55]. PIT using peptides from the phospholipase A2 bee venom allergen has led to reduced T cell proliferation to those peptides and altered cytokine profiles e. g. by increasing IL-10, in some studies [36,56,57]. PIT has also been found to reduce the severity of allergic responses to deliberate bee stings [56].

PIT can therefore improve clinical outcomes in allergic patients in some instances. Furthermore, although PIT studies have so far focused on aeroallergens or venom allergies, future application of PIT for the treatment of food allergies is also a possibility, particularly given the continued identification of food allergen derived $\mathrm{T}$ cell epitopes [58]. It is, however, apparent from clinical studies so far that the effects of PIT can be variable and therapeutic effects are not necessarily seen across all clinical readouts. These inconsistencies are likely due in part to inter-trial variability of factors such as clinical readouts, PIT regimens, nature of disease and whether patients have received immunotherapy previously, which can complicate the assessment of clinical effectiveness.

\section{Difficulties with PIT}

\section{Does PIT remove the risk of anaphylaxis}

\section{associated with SIT?}

The need to avoid severe IgE-driven hypersensitivity reactions, including anaphylaxis, is the primary reason why PIT rather than SIT may be more applicable to treating allergic children. Crucially, anaphylaxis and other severe hypersensitivity reactions are extremely rare after PIT. However, a PIT trial involving multiple sclerosis (MS) patients was halted due to a number of hypersensitivity reactions [59]. The peptide used contained sequence alterations designed to improve its therapeutic effects [an altered peptide ligand (APL), further discussed below]. Interestingly, it was levels of IgG1 and not IgE which were elevated in patients displaying hypersensitivity reactions [59]. This potential for generation of anaphylaxis-promoting peptide-specific IgG1 should be noted, although importantly this has not been reported in PIT allergy studies.

\section{Long-term disease exacerbation}

To our knowledge, there are no reports of PIT inducing long-term exacerbation of allergic disease. However, a phase II PIT trial using an APL in MS patients was discontinued due to disease exacerbations [60]. The APL displayed low immunogenicity and good tolerogenic potential in vitro yet seemed to promote an inflammatory $\mathrm{T}$ cell response in some patients. Exacerbation of disease has also been noted to occur using an unaltered peptide in a murine allergy model [61]. These rare examples highlight that there is a small risk that peptide administration may induce an inflammatory instead of a tolerogenic response in some circumstances, illustrating the need for incisive understanding of the mechanisms involved in PIT.

\section{Late Asthmatic Reactions}

PIT has induced late asthmatic reactions (LARs) in some patients during Fel d 1 allergy trials. LARs resulted in reduced lung function occurring at 2-3 hours following treatment and peaking at around 6 hours [62]. LARs were not associated with immediate hypersensitivity reactions/anaphylaxis. It appears that patients with certain HLA types are more likely to experience a LAR, although HLA type alone is not predictive of LAR development [63]. These MHC associations and the timing of LARs point to a $\mathrm{T}$ cell mediated mechanism implying that in some patients, cytokines produced by $\mathrm{T}$ cells responding to peptide can mediate airway hyperresponsiveness. Crucially, induction of LARs is not required in order to induce $\mathrm{T}$ cell tolerance [53] and LARs can be managed by careful regimen planning. In patients who have developed a LAR with PIT, repeating treatment within 2 to 8 weeks using the same dose of peptide induces $\mathrm{T}$ cell tolerance without promoting further LARs [53].

\section{Challenges of applying PIT to a diverse population, with particular regard to children}

HLA variation $\mathrm{CD}^{+} \mathrm{T}$ cells recognise peptide in the context of MHC II and TCR specificity for a peptide is a function of the peptide itself and the MHC II it is presented on. The polygenicity and polymorphic nature of the human leucocyte antigen (HLA) region means that there is extensive variation in the MHC II molecules expressed by different individuals. Most allergens will contain multiple peptide epitopes which can vary in their ability to bind to different MHC II molecules [64], meaning that there will be differences in the allergenderived peptides which are recognised by different patients' $T$ cells. This poses difficulties for identifying immunodominant peptides capable of inducing tolerance in a HLA-diverse patient population [10]. HLA class II allele associations have been described for 
allergic diseases [65], yet the complex nature of allergy means that, with the exception of coeliac disease [66], these associations are weaker than for many autoimmune diseases [67]. Although technically possible to characterise immunodominant peptides on an individual patient basis, this approach is unlikely to be feasible both in terms of cost and practicality [68]. But HLA diversity does not preclude the application of PIT to a diverse population [68]. Peptides exhibit considerable promiscuity in their ability to bind to MHC II molecules. A single peptide may bind to MHC II molecules derived from multiple HLA loci [e.g. HLA-DP, -DQ and -DR [69]], and/or to multiple alleles of an HLA molecule [(e.g. HLA-DR1 and HLA-DR53) [70]]. Additionally, use of multiple, overlapping allergen-derived peptides increases the likelihood that a PIT vaccine will contain peptides recognised by a range of HLA-disparate individuals. These characteristics, together with the fact that some HLA types are more common than others, means that a strategic selection of a small number of allergenic peptides could be used to treat a wide range of patients.

Nature of the peptide There are advantages to altering the sequence of a therapeutic peptide. APLs have defined amino acid substitutions which can change MHC and/or TCR binding properties of the peptide [21]. Different alterations can modulate the $\mathrm{T}$ cell response elicited by the peptide e.g. APLs that instead of inducing an allergy-associated Th2 $\mathrm{T}$ cell response, generate a Th1 response. The latter induces cytokines such as interferon- $\gamma$ (IFN- $\gamma$ ) which can sometimes antagonise allergic responses [71] and has been found to be expressed by an increased frequency of $\mathrm{CD} 4^{+}$ cells in some PIT studies [72]. The stimulatory capacity of a peptide can also be modulated. A "superagonist" APL has an increased ability to stimulate a T cell response whereas an "antagonist" APL can inhibit T cell activation, even in the presence of an agonist. Antagonists have obvious therapeutic applications and have been shown capable of preventing disease in animal models $[73,74]$. There is concern, however, that an APL defined as an antagonist from its effect in vitro on $\mathrm{T}$ cells with a limited TCR repertoire may behave differently in vivo on encountering a more diverse $\mathrm{T}$ cell repertoire [75]. Using APL antagonists therefore risks unpredictable effects, borne out by the aforementioned MS trial [60].

Other applications of APLs could be more amenable to clinical translation. For example, APLs can be generated to reduce the allergenicity of a peptide. Leech et al altered a myelin-based peptide reducing its IgG1 binding affinity while maintaining its tolerising capacity [76]. Hence, whilst antagonist APLs may not have widespread application, the potential to alter peptides to improve tolerogenicity or reduce allergenicity should not be dismissed.

Route The most desirable route of delivery of PIT for children would be oral or intranasal as they are minimally distressing. PIT delivered in these ways can be effective in inducing tolerance $[32,77]$, raising hope that these routes may be applicable to the treatment of allergic children in future. It is also possible that a sublingual approach, which has been used to deliver SIT [78], may also prove applicable to PIT. At present however, most allergy-based clinical studies focus on subcutaneous or intradermal PIT administration.

Dose and Regimen There remains no clear consensus as to the optimal peptide dose or regimen which have varied considerably in different trials [49-51,79]. Doseescalation is advantageous because it is less likely to cause adverse effects and, if side effects such as a LAR develop following a particular dosage, withholding dosage increase until LAR is no longer provoked can be effective [79]. Different regimens may induce different tolerogenic mechanisms. For example, high dose regimens may be more likely to promote a deletional mechanism of tolerance [25] whereas lower dose or multi-dose regimens may provoke induction of IL-10 producing cells capable of regulation [26,35]. Hence, low dose, incremental regimens may be more attractive therapeutically because of the potential for production of regulatory $\mathrm{T}$ cells which could exert their effects on pathogenic $\mathrm{T}$ cells reactive to other allergens.

A key question is how long PIT needs to be given to induce long-term tolerance? Limited data on this exist from PIT allergy studies which to date have focused on short-term clinical outcomes. However, tolerance following SIT has been demonstrated up to 7 years after completion of treatment [80]. Although these studies involve initial up-dosing followed by maintenance dosing for around 3 years, the frequency and duration of maintenance dosing necessary for long-term tolerance remains undefined. For PIT it is probable that a maintenance regimen will be required to generate long-term tolerance. Ideally such a regimen would be infrequent to encourage compliance, particularly for children. Additionally, maintenance dosage will need to be determined. A high maintenance dose may risk adverse events, particularly if a child has missed a previous dose. Indeed, a review of near fatal reactions to SIT found the majority occurred during maintenance and not during up-dosing [81]. It would be ideal if a low, infrequent maintenance dose was capable of preserving long-term tolerance.

Concurrent illness Concurrent illness may hold particular relevance for application of PIT to children. Data concerning this do not exist for PIT. However, giving SIT during concurrent systemic illness has been 
associated with fatalities [20] and current guidelines advise against giving SIT during an acute systemic illness [82]. It may be that giving SIT during a period of systemic inflammation can precipitate an inflammatory response and exacerbate disease. It would therefore be advisable to apply these conditions to the use of PIT. There is, however, a lack of data concerning immunotherapy and concurrent viral infection. Children experience a higher frequency of viral infections than adults. Such infections may not cause systemic illness or fever but may still locally activate immune cells such as DCs [83]. Peptide presented to T cells by DCs which have been activated by a viral infection theoretically risks incurring an inflammatory response rather than a tolerant one. Interestingly, in a murine allergic airways model, concurrent influenza infection prevented tolerance induced by intranasal SIT and enhanced allergic inflammation of the airways [84]. In a different study, allergen exposure via the airways at the time of viral infection induced allergen-specific IgG1 and subsequently led to anaphylaxis upon allergen re-exposure [85]. Clearly, these examples may only represent the effects of exposure to whole protein allergen, not peptide, during severe, systemic viral infection. It is thus important to address whether a variety of viral infections, particularly mild non-systemic ones, have any detrimental impact on the outcome of PIT.

\section{Conclusions}

PIT holds promise for the treatment and modification of allergic disease. There have been significant advances in the application of PIT to adult allergic patients, and there is substantial scope for future opportunities for the application of PIT. Yet to maximise therapeutic efficacy necessitates translation to allergic children. For this, further understanding of the underlying mechanisms involved in PIT, potential confounding factors such as viral infection and the interplay between dose, regimen and route need to be further elucidated. Mechanistic studies utilising experimental models together with carefully structured, appropriately powered clinical trials looking at a host of outcome measures should aid future translation to the paediatric clinic.

\section{List of abbreviations}

APL: altered peptide ligand; GATA-3: GATA-binding protein 3; HLA: human leukocyte antigen; LARs: late asthmatic reactions; LPS: lipopolysaccharide; MHC: major histocompatibility complex; PBMC: peripheral blood mononuclear cells; PIT: peptide immunotherapy; SIT: specific immunotherapy; TCR: T cell receptor

\section{Author details}

${ }^{1}$ MRC Centre for Inflammation Research, The University of Edinburgh, Edinburgh, UK. ${ }^{2}$ Child Life and Health, The University of Edinburgh, Edinburgh, UK. ${ }^{3}$ Centre for Multiple Sclerosis Research, The University of Edinburgh, Edinburgh, UK.

\section{Authors' contributions}

All 3 authors framed the scope of the article, KJM wrote the article and SMA and JS contributed to refine the substance. All authors read and approved the final manuscript.

\section{Competing interests}

The authors declare that they have no competing interests.

Received: 11 August 2011 Accepted: 7 November 2011 Published: 7 November 2011

\section{References}

1. Punekar YS, Sheikh A: Establishing the sequential progression of multiple allergic diagnoses in a UK birth cohort using the General Practice Research Database. Clin Exp Allergy 2009, 39:1889-1895.

2. Barnes PJ, Jonsson B, Klim JB: The costs of asthma. Eur Respir J 1996, 9:636-642

3. Holgate ST: A look at the pathogenesis of asthma: the need for a change in direction. Discovery medicine 2010, 9:439-447.

4. Leckie MJ, Brinke At, Khan J, Diamant Z, O'Connor BJ, Walls CM, Mathur AK, Cowley HC, Chung KF, Djukanovic R, Hansel TT, Holgate ST, Sterk PJ, Barnes PJ: Effects of an interleukin-5 blocking monoclonal antibody on eosinophils, airway hyper-responsiveness, and the late asthmatic response. Lancet 2000, 356:2144-2148.

5. Haldar P, Brightling CE, Hargadon B, Gupta S, Monteiro W, Sousa A, Marshall RP, Bradding P, Green RH, Wardlaw AJ, Pavord ID: Mepolizumab and exacerbations of refractory eosinophilic asthma. N Engl J Med 2009, 360:973-984.

6. Sears MR, Greene JM, Willan AR, Wiecek EM, Taylor DR, Flannery EM, Cowan JO, Herbison GP, Silva PA, Poulton R: A longitudinal, populationbased, cohort study of childhood asthma followed to adulthood. $N$ Engl J Med 2003, 349:1414-1422.

7. Boyle RJ, Tang MLK: Can allergic diseases be prevented prenatally? Allergy 2006, 61:1423-1431.

8. Warner JO: The early life origins of asthma and related allergic disorders. Arch Dis Child 2004, 89:97-102.

9. Pajno GB, Barberio G, De Luca F, Morabito L, Parmiani S: Prevention of new sensitizations in asthmatic children monosensitized to house dust mite by specific immunotherapy. A six-year follow-up study. Clin Exp Allergy 2001, 31:1392-1397.

10. Larche M, Wraith DC: Peptide-based therapeutic vaccines for allergic and autoimmune diseases. Nat Med 2005, 11:S69-76.

11. Akdis $M$, Akdis CA: Therapeutic manipulation of immune tolerance in allergic disease. Nat Rev Drug Discov 2009, 8:645-660.

12. Lloyd CM, Hessel EM: Functions of T cells in asthma: more than just Th2 cells. Nat Rev Immunol 2010, 10:838-848.

13. Noon L: Prophylactic innoculation against hay fever. Lancet 1911, i:1572-1573.

14. Frew AJ: Allergen immunotherapy. J Allergy Clin Immunol 2010, 125: S306-313.

15. Norman PS: Immunotherapy: 1999-2004. J Allergy Clin Immunol 2004 113:1013-1023

16. Durham SR, Emminger W, Kapp A, Colombo G, de Monchy JGR, Rak S, Scadding GK, Andersen JS, Riis B, Dahl R: Long-term clinical efficacy in grass pollen-induced rhinoconjunctivitis after treatment with SQstandardized grass allergy immunotherapy tablet. J Allergy Clin Immunol 2010, 125:131-138

17. Jacobsen L, Valovirta E: How strong is the evidence that immunotherapy in children prevents the progression of allergy and asthma? Curr Opin Allergy Clin Immunol 2007, 7:556-560.

18. Caubet JC, Eigenmann PA: Late side-effects during systemic immunotherapy in children. Allergy 2008, 63:1561-1562.

19. Peavy RD, Metcalfe DD: Understanding the mechanisms of anaphylaxis. Curr Opin Allergy Clin Immunol 2008, 8:310-315.

20. Borchers A, Keen C, Gershwin M: Fatalities following allergen immunotherapy. Clin Rev Allergy Immunol 2004, 27:147-158.

21. Anderton SM: Peptide-based immunotherapy of autoimmunity: a path of puzzles, paradoxes and possibilities. Immunology 2001, 104:367-376.

22. Liu GY, Wraith DC: Affinity for class II MHC determines the extent to which soluble peptides tolerize autoreactive T cells in naive and primed adult mice-implications for autoimmunity. Int Immunol 1995, 7:1255-1263. 
23. Wraith DC: Therapeutic peptide vaccines for treatment of autoimmune diseases. Immunol Lett 2009, 122:134-136.

24. Larché M: Peptide immunotherapy for allergic diseases. Allergy 2007, 62:325-331.

25. Hochweller $K$, Anderton SM: Kinetics of costimulatory molecule expression by $T$ cells and dendritic cells during the induction of tolerance versus immunity in vivo. Eur J Immunol 2005, 35:1086-1096.

26. Gabrysova L, Nicolson KS, Streeter HB, Verhagen J, Sabatos-Peyton CA, Morgan DJ, Wraith DC: Negative feedback control of the autoimmune response through antigen-induced differentiation of IL-10-secreting Th1 cells. J Exp Med 2009, 206:1755-1767.

27. Koffeman EC, Genovese M, Amox D, Keogh E, Santana E, Matteson EL, Arthur K, Jerry AM, Michael HS, James OP, Joan MB, Alan JK, Rodrigo S, Francis B, Carolyn D, Theo van den B, Femke van W, Xiao Z, Peter Z, Tho L, Berent AP, Gary CC, Salvatore A: Epitope-specific immunotherapy of rheumatoid arthritis: Clinical responsiveness occurs with immune deviation and relies on the expression of a cluster of molecules associated with T cell tolerance in a double-blind, placebo-controlled, pilot phase II trial. Arthritis Rheum 2009, 60:3207-3216.

28. Ohnmacht C, Pullner A, King SBS, Drexler I, Meier S, Brocker T, Voehringer $D$ : Constitutive ablation of dendritic cells breaks selftolerance of CD4 T cells and results in spontaneous fatal autoimmunity. J Exp Med 2009, 206:549-559.

29. Kunkel D, Kirchhoff D, Volkmer-Engert R, Radbruch A, Scheffold A: Sensitive visualization of peptide presentation in vitro and ex vivo. Cytometry Part A 2003, 54A:19-26.

30. Haase C, Yu L, Eisenbarth G, Markholst H: Antigen-dependent immunotherapy of non-obese diabetic mice with immature dendritic cells. Clin Exp Immunol 2010, 160:331-339.

31. Lambrecht $\mathrm{BN}$, Hammad H: Biology of lung dendritic cells at the origin of asthma. Immunity 2009, 31:412-424.

32. Gabryšová L, Wraith DC: Antigenic strength controls the generation of antigen-specific IL-10-secreting T regulatory cells. Eur J Immunol 2010, 40:1386-1395.

33. Janssen EM, van Oosterhout AJM, Nijkamp FP, van Eden W, Wauben MHM The efficacy of immunotherapy in an experimental murine model of allergic asthma is related to the strength and site of T cell activation during immunotherapy. J Immunol 2000, 165:7207-7214.

34. Ryan KR, Patel SD, Stephens LA, Anderton SM: Death, adaptation and regulation: The three pillars of immune tolerance restrict the risk of autoimmune disease caused by molecular mimicry. J Autoimmun 2007, 29:262-271.

35. Campbell JD, Buckland KF, McMillan SJ, Kearley J, Oldfield WLG, Stern LJ, Gronlund H, van Hage M, Reynolds CJ, Boyton RJ, Cobbold SP, Kay AB, Altmann DM, Lloyd CM, Larche M: Peptide immunotherapy in allergic asthma generates IL-10-dependent immunological tolerance associated with linked epitope suppression. J Exp Med 2009, 206:1535-1547.

36. Fellrath J-M, Kettner A, Dufour N, Frigerio C, Schneeberger D, Leimgruber A, Corradin G, Spertini F: Allergen-specific T-cell tolerance induction with allergen-derived long synthetic peptides: Results of a phase I trial. $J$ Allergy Clin Immunol 2003, 111:854-861.

37. Liblau RS, Tisch R, Shokat K, Yang X, Dumont N, Goodnow CC, McDevitt HO: Intravenous injection of soluble antigen induces thymic and peripheral T-cells apoptosis. Proc Natl Acad Sci USA 1996, 93:3031-3036.

38. Schwartz RH: T Cell Anergy. Annu Rev Immunol 2003, 21:305-334.

39. Pape KA, Merica R, Mondino A, Khoruts A, Jenkins MK: Direct evidence that functionally impaired $C D 4+T$ cells persist in vivo following induction of peripheral tolerance. J Immunol 1998, 160:4719-4729.

40. Verhoef A, Alexander C, Kay AB, Larche M: T cell epitope immunotherapy induces a CD4+ T cell population with regulatory activity. PLoS Med 2005, 2:e78

41. Smith TRF, Alexander C, Kay AB, Larché M, Robinson DS: Cat allergen peptide immunotherapy reduces CD4+ T cell responses to cat allergen but does not alter suppression by CD4+ CD25+ T cells: a double-blind placebo-controlled study. Allergy 2004, 59:1097-1101.

42. Sakaguchi S, Yamaguchi T, Nomura T, Ono M: Regulatory T cells and immune tolerance. Cell 2008, 133:775-787.

43. van Rijt LS, Vos N, Willart M, Muskens F, Tak PP, van der Horst C, Hoogsteden HC, Lambrecht BN: Persistent activation of dendritic cells after resolution of allergic airway inflammation breaks tolerance to inhaled allergens in mice. Am J Respir Crit Care Med 2011, 184:303-311.

44. Kretschmer K, Apostolou I, Hawiger D, Khazaie K, Nussenzweig MC, von Boehmer H: Inducing and expanding regulatory $\mathrm{T}$ cell populations by foreign antigen. Nat Immunol 2005, 6:1219-1227.

45. Meiler F, Zumkehr J, Klunker S, Ruckert B, Akdis CA, Akdis M: In vivo switch to IL-10-secreting $T$ regulatory cells in high dose allergen exposure. J Exp Med 2008, 205:2887-2898.

46. Radulovic S, Jacobson MR, Durham SR, Nouri-Aria KT: Grass pollen immunotherapy induces Foxp3-expressing CD4+CD25+ cells in the nasal mucosa. J Allergy Clin Immunol 2008, 121:1467-1472, e1461.

47. Francis JN, Till SJ, Durham SR: Induction of IL-10+CD4+CD25+ T cells by grass pollen immunotherapy. J Allergy Clin Immunol 2003, 111:1255-1261.

48. Moldaver D, Larche M: Immunotherapy with peptides. Allergy 2011, 66:784-791.

49. Norman PS, Ohman LN Jr, Long AA, Creticos PS, Gefter MA, Z S: Treatment of cat allergy with T-cell reactive peptides. Am J Respir Crit Care Med 1996, 154:1623-1628.

50. Maguire P, Nicodemus C, Robinson D, Aaronson D, Umetsu DT: The Safety and Efficacy of ALLERVAX CAT in Cat Allergic Patients. Clin Immunol 1999, 93:222-231.

51. Pene J, Desroches A, Paradis L, Lebel B, Farce M, Nicodemus C, Yssel H, Bousquet J: Immunotherapy with Fel d 1 peptides decreases IL-4 release by peripheral blood T cells of patients allergic to cats. J Allergy Clin Immunol 1998, 102:571-578.

52. Simons FER, Imada M, Li Y, Watson WTA, HayGlass KT: Fel d 1 peptides: effect on skin tests and cytokine synthesis in cat-allergic human subjects. Int Immunol 1996, 8:1937-1945.

53. Oldfield WLG, Kay AB, Larche M: Allergen-derived T cell peptide-induced late asthmatic reactions precede the induction of antigen-specific hyporesponsiveness in atopic allergic asthmatic subjects. J Immunol 2001, 167:1734-1739.

54. Alexander C, Tarzi M, Larche M, Kay AB: The effect of Fel d 1-derived T-cell peptides on upper and lower airway outcome measurements in catallergic subjects. Allergy 2005, 60:1269-1274.

55. Ruëff F, Przybilla B, Biló MB, Müller U, Scheipl F, Aberer W, Birnbaum J, Bodzenta-Lukaszyk A, Bonifazi F, Bucher C, Campi P, Darsow U, Egger C, Haeberli G, Hawranek T, Kucharewicz I, Küchenhoff H, Lang R, Quercia O, Reider N, Severino M, Sticherling M, Sturm GJ, Wüthrich B: Predictors of side effects during the buildup phase of venom immunotherapy for hymenoptera venom allergy: The importance of baseline serum tryptase +. J Allergy Clin Immunol 2010, 126:105-111.

56. Müller U, Akdis CA, Fricker M, Akdis M, Blesken T, Bettens F, K B: Successful immunotherapy with T-cell epitope peptides of bee venom phospholipase A2 induces specific T cell anergy in patients allergic to bee venom. J Allergy Clin Immunol 1998, 101:747-754.

57. Tarzi M, Klunker S, Texier C, Verhoef A, Stapel SO, Akdis CA, Maillere B, Kay $A B$, Larché $M$ : Induction of interleukin-10 and suppressor of cytokine signalling-3 gene expression following peptide immunotherapy. Clin Exp Allergy 2006, 36:465-474.

58. Prickett SR, Voskamp AL, Dacumos-Hill A, Symons K, Rolland JM, O'Hehir RE: Ara $\mathrm{h} 2$ peptides containing dominant CD4+ T-cell epitopes: candidates for a peanut allergy therapeutic. J Allergy Clin Immunol 2011, 127:608-615, e601-605.

59. Kappos L, Comi G, Panitch H, Oger J, Antel J, Conlon P, Steinman L, Comi G, Kappos L, Oger J, Panitch H, Rae-Grant A, Castaldo J, Eckert N, Guarnaccia JB, Mills P, Johnson G, Calabresi PA, Pozzilli C, Bastianello S, Giugni E, Witjas T, Cozzone P, Pelletier J, Pohlau D, Przuntek H, Hoffmann V, Bever C, Katz E, Clanet M, Berry I, Brassat D, Brunet I, Edan G, Duquette P, Radue E-W, Schott D, Lienert C, Taksaoui A, Rodegher M, Filippi M, Evans A, Bourgouin P, Zijdenbos A, Salem S, Ling N, Alleva D, Johnson E, Gaur A, Crowe $P$, Liu X-J: Induction of a non-encephalitogenic type $2 \mathrm{~T}$ helpercell autoimmune response in multiple sclerosis after administration of an altered peptide ligand in a placebo-controlled, randomized phase II trial. Nat Med 2000, 6:1176-1182.

60. Bielekova B, Goodwin B, Richert N, Cortese I, Kondo T, Afshar G, Gran B, Eaton J, Antel J, Frank JA, McFarland HF, Martin R: Encephalitogenic potential of the myelin basic protein peptide (amino acids 83-99) in multiple sclerosis: Results of a phase II clinical trial with an altered peptide ligand. Nat Med 2000, 6:1167-1175. 
61. Janssen EM, Wauben MHM, Jonker EH, Hofman G, Van Eden W, Nijkamp FP, VanOosterhout AJM: Opposite effects of immunotherapy with ovalbumin and the immunodominant T-cell epitope on airway eosinophilia and hyperresponsiveness in a murine model of allergic asthma. Am J Respir Cell Mol Biol 1999, 21:21-29.

62. Haselden BM, Barry Kay A, Larche M: Immunoglobulin E-independent major histocompatibility complex-restricted T cell peptide epitopeinduced late asthmatic reactions. J Exp Med 1999, 189:1885-1894.

63. Larche M, Haselden BM, Oldfield WLG, Shirley K, North J, Meng Q, Robinson DS, Ying S, Kay AB: Mechanisms of T cell peptide epitopedependent late asthmatic reactions. Int Arch Allergy Immunol 2001, 124:272-275

64. Oseroff C, Sidney J, Kotturi MF, Kolla R, Alam R, Broide DH, Wasserman SI, Weiskopf D, McKinney DM, Chung JL, Petersen A, Grey H, Peters B, Sette A: Molecular determinants of $T$ cell epitope recognition to the common timothy grass allergen. J Immunol 2010, 185:943-955.

65. Munthe-Kaas MC, Carlsen KL, Carlsen KH, Egeland T, Håland G, Devulapalli CS, Akselsen H, Undlien D: HLA Dr-Dq haplotypes and the TNFA-308 polymorphism: associations with asthma and allergy. Allergy 2007, 62:991-998.

66. Schuppan D, Junker $Y$, Barisani D: Celiac disease: from pathogenesis to novel therapies. Gastroenterology 2009, 137:1912-1933.

67. Caillat-Zucman S: Molecular mechanisms of HLA association with autoimmune diseases. Tissue Antigens 2009, 73:1-8.

68. Larché M: Of cats and men: immunodominance and the role of HLA-DP/ DQ. Clin Exp Allergy 2008, 38:1709-1711.

69. Friedl H, Spangfort, Schou, Breiteneder, Joost Van N: Identification of a highly promiscuous and an HLA allele-specific T-cell epitope in the birch major allergen Bet v 1: HLA restriction, epitope mapping and TCR sequence comparisons. Clin Exp Allergy 1999, 29:478-487.

70. Kobayashi H, Wood M, Song Y, Appella E, Celis E: Defining promiscuous MHC class II helper T-cell epitopes for the HER2/neu tumor antigen. Cancer Res 2000, 60:5228-5236.

71. Kinnunen T, Jutila K, Kwok WW, Rytkönen-Nissinen M, Immonen A, Saarelainen S, Närvänen A, Taivainen A, Virtanen T: Potential of an altered peptide ligand of lipocalin allergen Bos $\mathrm{d} 2$ for peptide immunotherapy. J Allergy Clin Immunol 2007, 119:965-972.

72. Alexander C, Ying S, B Kay A, Larché M: Fel d 1-derived T cell peptide therapy induces recruitment of CD4+CD25+; CD4+ interferon- $\gamma+T$ helper type 1 cells to sites of allergen-induced late-phase skin reactions in cat-allergic subjects. Clin Exp Allergy 2005, 35:52-58.

73. Kuchroo VK, Greer JM, Kaul D, Ishioka G, Franco A, Sette A, Sobel RA, Lees MB: A single TCR antagonist peptide inhibits experimental allergic encephalomyelitis mediated by a diverse T cell repertoire. J Immunol 1994, 153:3326-3336.

74. Sakurai Y, Brand DD, Tang B, Rosloniec EF, Stuart JM, Kang AH, Myers LK: Analog peptides of type II collagen can suppress arthritis in HLA-DR4 (DRB1*0401) transgenic mice. Arthritis Res Ther 2006, 8:R150.

75. Anderton SM, Manickasingham SP, Burkhart C, Luckcuck TA, Holland SJ, Lamont AG, Wraith DC: Fine specificity of the myelin-reactive $T$ cell repertoire: implications for TCR antagonism in autoimmunity. $J$ Immunol 1998, 161:3357-3364.

76. Leech MD, Chung C, Culshaw A, Anderton SM: Peptide-based immunotherapy of experimental autoimmune encephalomyelitis without anaphylaxis. Eur J Immunol 2007, 37:3576-3581.

77. Gonnella P, Del Nido P, McGowan F: Oral tolerization with cardiac myosin peptide (614-629) ameliorates experimental autoimmune myocarditis: role of Stat 6 genes in BALB/CJ mice. J Clin Immunol 2009, 29:434-443.

78. Radulovic S, Wilson D, Calderon M, Durham S: Systematic reviews of sublingual immunotherapy (SLIT). Allergy 2011, 66:740-752.

79. Oldfield WLG, Larché M, Kay AB: Effect of T-cell peptides derived from Fel d 1 on allergic reactions and cytokine production in patients sensitive to cats: a randomised controlled trial. Lancet 2002, 360:47-53.

80. Jacobsen L, Niggemann B, Dreborg S, Ferdousi HA, Halken S, Høst A, Koivikko A, Norberg LA, Valovirta E, Wahn U, Möller C: Specific immunotherapy has long-term preventive effect of seasonal and perennial asthma: 10-year follow-up on the PAT study. Allergy 2007, 62:943-948.

81. Amin HS, Liss GM, Bernstein Dl: Evaluation of near-fatal reactions to allergen immunotherapy injections. J Allergy Clin Immunol 2006, 117:169-175.
82. Zuberbier T, Bachert C, Bousquet PJ, Passalacqua G, Walter Canonica G, Merk H, Worm M, Wahn U, Bousquet J: GA2LEN/EAACl pocket guide for allergen-specific immunotherapy for allergic rhinitis and asthma. Allergy 2010, 65:1525-1530.

83. Beyer M, Bartz H, Hörner K, Doths S, Koerner-Rettberg C, Schwarze J: Sustained increases in numbers of pulmonary dendritic cells after respiratory syncytial virus infection. J Allergy Clin Immunol 2004, 113:127-133.

84. Tsitoura DC, Kim S, Dabbagh K, Berry G, Lewis DB, Umetsu DT: Respiratory infection with influenza $A$ virus interferes with the induction of tolerance to aeroallergens. J Immunol 2000, 165:3484-3491.

85. O'Donnell DR, Openshaw PJ: Anaphylactic sensitization to aeroantigen during respiratory virus infection. Clin Exp Allergy 1998, 28:1501-1508.

doi:10.1186/2045-7022-1-13

Cite this article as: Mackenzie et al:: Peptide immunotherapy for childhood allergy - addressing translational challenges. Clinical and Translational Allergy 2011 1:13.

\section{Submit your next manuscript to BioMed Central and take full advantage of:}

- Convenient online submission

- Thorough peer review

- No space constraints or color figure charges

- Immediate publication on acceptance

- Inclusion in PubMed, CAS, Scopus and Google Scholar

- Research which is freely available for redistribution

Submit your manuscript at www.biomedcentral.com/submit
C) Biomed Central 